\title{
The Norwegian Criminal Regulation of Drugs: An Overview and Some Principled Challenges
}

\author{
JØRN JACOBSEN \& SELMA TASLAMAN ${ }^{\star}$
}

\section{Introduction}

This article has two main purposes. The first main purpose is to describe the current state of the Norwegian criminal regulation of drugs. ${ }^{1}$ In Norwegian criminal law, illegal drugs are harshly and extensively regulated, at least by Norwegian standards. As we will return to, the Norwegian criminal regulation of drugs consists mainly of two offences: a general offence related primarily to professional involvement in drugs, and an offence that specifically targets the users of drugs. In sum this regulation is extensive, as more or less all involvement in drugs is punishable. It is also harsh, in the sense that these offences cover the entire 'normal' scale of punishment applicable in Norwegian criminal law.

The second main purpose of the article is to identify particular challenges to the debates on the Norwegian criminal regulation of drugs. Drugs and criminal law concern a number of more general intellectual, moral and political challenges. ${ }^{2}$ In this article, particular emphasis will be placed on how these challenges find their way into the Norwegian debate on the criminal regulation of drugs. This debate has mainly considered policy-related

* Respectively, Professor and Research Assistant at the Faculty of Law, University of Bergen.

1 To our knowledge, the criminal regulation of drugs in Norway has not previously been outlined in English. All translations from Norwegian to English in the following are carried out by the authors for the purpose of this article.

2 See for instance in this volume, Husak, 'Thoughts on Drug Policy, Public Health, and Crime: More Support for Decriminalization'.

This is an Open-access article distributed under the terms of the Creative Commons Attribution 3.0 Unported License (http://creativecommons.org/licenses/ by/3.0/), permitting all use, distribution, and reproduction in any medium, provided the original work is properly cited. 
arguments, concerning the effects of legalisation contra criminalisation. We do not challenge the relevance of this perspective. ${ }^{3}$ However, a more clear-cut theoretical perspective on the subject is needed to get the debate on the right track.

We find the adoption of a harm-principle in the preparatory works of the Penal Code of 2005 to be a useful starting point for this kind of theoretical enterprise. However, the preparatory works cannot be said to have exploited the potential in this regard, and the reasoning is open to criticism on many counts. In this paper, we aim to outline a more promising approach. We will not, however, attempt to provide any clear-cut answers to questions such as the (hotly debated) issue of whether drug use should be criminalised or not. Rather, by identifying a number of challenges that must be addressed in particular by those who do want to uphold and justify the contemporary regulation, we provide a better starting point for a more thorough debate. After all, in a democratic Rechtsstaat where the individual freedom of action is a fundamental value, it is the criminalisation of (for instance) drug use that must be justified, not the legalisation. ${ }^{4}$ Regardless of which solution one argues for, there should be a common interest in clarifying the arguments to the highest degree possible. We will also briefly comment on the most recent development in Norway, where a decision by the Parliament now seems to imply a shift of focus from punishment to a health perspective on drugs. The implications of this decision to our subject is, as we shall see, far from clear. Finally, we will address the high level of punishment for drug crimes in Norwegian criminal law.

\section{The Contemporary Norwegian Criminal Regulation of Drugs}

As mentioned, there are two offences that directly target drug-related acts. ${ }^{5}$ First of all, there is the 'general' offence in s. 231 of the Penal Code. ${ }^{6}$ This offence covers more or less any kind of involvement in drugs, or narkotika. It criminalises the production, import, export, acquisition, possession, transferal or sale of drugs. It primarily aims to target organised drug crimes, but is not at all limited to this. Generally, we may say that little

3 See also Marthinussen in this volume.

4 See also e.g. Husak in Husak and de Marneffe, The Legalization of Drugs, For \& Against (Cambridge University Press, 2005) p. 38.

5 The existing literature consist mainly of commentaries and brief outlines, most recently Matningsdal, Norsk spesiell strafferett, $2^{\text {nd }}$ edition (Fagbokforlaget, 2016) pp. 23-68, and Matningsdal, Straffeloven - De straffbare handlingene, kommentarutgave (Universitetsforlaget 2017) pp. 359-418. See also, concerning the former Penal Code of 1902, e.g. Andenæs and Andorsen, Spesiell strafferett (Universitetsforlaget 2008) pp. $240 \mathrm{ff}$. Apart from this, the literature consist mainly of critical perspectives (see further below) and/or sociological and criminological perspectives on the subject, see for instance Flaatten, Heroinister og kontorister: en undersøkelse av maktens ulike fasetter i rettsforfølgelsen av narkotikalovbrudd (Fagbokforlaget, 2007).

$6 \quad$ Lov om straff (straffeloven) av 20. mai 2005 nr. 28. 
involvement in drugs is required in order to violate this provision. The Penal Code also outlaws attempts at, and participation in, the acts mentioned in s. 231. This follows from ss. 16 and 15 of the general provisions, to which s. 231 makes no excepetion. ${ }^{7}$ As narkotika in this regard counts every substance that is listed in the so-called narkotikalisten (strictly translated: 'the narcotics list'). This list is continually updated by the Norwegian Medicines Agency. ${ }^{8}$

Secondly, the Medicine Act of 1992 regulates a wide range of activities related to medicine production and more. ${ }^{9}$ Chapter VIII of this Act also regulates drugs. There is a general prohibition of use and possession of drugs in s. 24, and violations of the provision are sanctioned by the second part of the general threat of punishment in s. 31 of the Act. Also here, participation in crime is subject to criminal responsibility. Attempts, however, are not. As we will return to, breaches of s. 24 do not warrant a sufficiently long term of imprisonment (i.e. one year) to activate criminal responsibility for attempts.

Both of these rules are criminal rules. The latter is, however, part of what is termed den strafferettslege spesiallovgivningen. ${ }^{10}$ This largely corresponds to the German notion of Nebenstrafrecht, where the threat of punishment is applied to rules in other codes than the criminal code, which primarily concerns administrative matters. These are often considered to be less serious offences. The primary difference in this regard is the already signalled milder threat of punishment in the Medicine Act than in the Penal Code. We will return to this.

The relation between the two offences is complex due to the fact that s. 231 of the Penal Code and s. 24 of the Medicine Act s. 24 both consider possession as a violation. However, the Norwegian terms applied differ: The Penal Code contains the term oppbevaring, whereas the Medicine Act uses the term besittelse. This difference in terms is a key to understanding the more specific relation between the two provisions. Possession in the Penal Code covers all kinds of possession that lasts for a longer period of time, that concerns a significant amount of drugs, and/or that aims at anything other than personal consumption. ${ }^{11}$ Possession in the sense of the Medicine Act is, for its part, limited to temporary possession with the aim of (immediate) own use. This also limits the possible amount of drugs that can be involved for the offence to be sanctioned by the Medicine Act: The quantity cannot be more than one to two units. Thus, the offence in the Medicine

7 See e.g. Gröning, Husabø and Jacobsen, Frihet, forbrytelse og straff (Fagbokforlaget, 2016) pp. $354 \mathrm{ff}$ and pp. $319 \mathrm{ff}$.

8 See https://lovdata.no/dokument/SF/forskrift/2013-02-14-199/KAPITTEL_1\#KAPITTEL_1, where the drug list is included as an appendix to the administrative drug regulation (last accessed 21.03.18)

$9 \quad$ Lov om legemidler m.v. (legemiddelloven) av. 12. april $1992 \mathrm{nr} .132$.

10 See for instance Gröning, Husabø and Jacobsen 2016 p. 10.

11 Cfr. Ot.prp. 23 (1983-1984) pp. 14-15 and p. 28, and also for instance Rt. 2005 p. 1319 sect. 14. 
Act has quite a limited scope compared to the offence in the Penal Code. Quantitatively, however, there are more instances of penal reactions for breaches of the former (7 796 in total in 2015, compared to 7386 penal reactions for violations of the drug provisions in the Penal Code). ${ }^{12}$

The fact that the different offences target different acts reflects itself in the available criminal sanctions. Violations of the prohibition of use and possession in the Medicine Act are sanctioned by fines or imprisonment up to 6 months ( 3 months more than for violations of other rules in the Medicine Act). This covers both intentional and negligent acts. ${ }^{13}$ Usually, such violations are sanctioned by a fine. However, a fine of this kind may bar one from certain jobs, lead to the withdrawal of one's driving license, and more.

Intentional breaches of s. 231 in the Penal Code are, for their part, sanctioned by a fine or imprisonment up to two years. Here, however, there is a complex set of alternatives (compared to the Medicine Act). First, negligent drug crimes are sanctioned by the separate second part of s. 231, where the threat of punishment is similar to the one in the Medicine Act: fine or imprisonment up to 6 months. Secondly, it follows from s. 232 first part that gross violations of s. 231 first part are sanctioned by imprisonment up to 10 years. Third, violations of s. 231 first part that consist in involvement with a very significant quantity of drugs, can be punished by imprisonment up to 15 years (see s. 232 second part, first sentence). Finally, when there are highly aggravating circumstances, the punishment can be 21 years of imprisonment (s. 232 second sentence). Section 232 third part sanctions negligent gross violations of s. 231 with a maximum of imprisonment for 6 years.

Where on the scale intentional offences shall be placed, depends on an overall assessment of the act performed. However, the outcome of this assessment is mainly determined by the form and quantity of the drug involved in the crime. More detailed guidelines were developed by the Director of Public Prosecutions and later approved by the Supreme Court and by the legislator as a basis for the Penal Code of $2005 .{ }^{14}$ To exemplify, the line between an 'ordinary' violation of s. 231 first part and gross violations of this provision (as sanctioned by s. 232 first part), is set at 15 grams for heroin, but at 1 kilo when the case concerns hashish. To bring the offence to the next level (very significant quan-

12 https://www.ssb.no/sosiale-forhold-og-kriminalitet/statistikker/straff/aar (last accessed 21.03.2018).

13 In Norway, this is conceptualised in a different manner than in Anglo-American criminal law. The Norwegian notion of forsett is closer to the German Vorsatz than intent in the Common law-style. Aktløyse is comparable to Fahrlässigkeit, whereas the Anglo-American notions of recklessness and negligence are both covered by this concept, in terms of grov and (as it is often coined, albeit not by the Penal Code itself) simpel. See further Gröning, Husabø and Jacobsen 2016 pp. 223-260.

14 See further Ot.prp. nr. 22 (2008-2009) Om lov om endringer i straffeloven 20. mai 2005 nr. 28 pp. $97 \mathrm{ff}$. and Matningsdal 2016 pp. $34 \mathrm{ff}$. for the background. 
tity, 15 years imprisonment), requires 750 grams of heroin and 80 kilos of hashish. The alternative concerning highly aggravating circumstances (up to 21 years imprisonment), however, is somewhat different. This requires not only a very significant quantity of drugs but also that the offender has had a particularly central role in the trafficking of drugs.

This shows that the punishment for violations of s. 231 of the Penal Code varies significantly depending on factors such as which type and amount of drug(s) the case concerns. From these factors, the Supreme Court has, in line with its general practice of setting standards for criminal sentencing, developed detailed standards for the lower courts to follow. These standards are the starting point for the courts in sentencing, followed up by a more nuanced sentencing in each case by reference to the many relevant sentencing factors in Norwegian criminal law (see here in particular ss. 77 and 78 of the Penal Code). Practice shows that courts apply the full scale of possible punishments, including 21 years of imprisonment. One particular high-profile example is the 21 -year prison sentence delivered to a higher police officer who was found guilty of participating in extensive import of hashish (the case has been appealed) ${ }^{15}$ Below we will return to the relatively high level of punishment for drug offences compared to other types of crimes.

To gain a full overview of the Norwegian criminal regulation of drug crimes, we need to take into account that there are also several other rules that add to the already extensive regulation. This goes, for instance, for the regulation of receiving proceeds from crime and laundering, which both increase the punishment when such acts are related to major drug offences (see ss. 333 and 338 of the Penal Code respectively). Also, there are a number of rules that increase the punishment (for procedural reasons), which do not explicitly target drug crimes but which are still highly relevant to drug cases. The obvious example of this is the many specific rules (both substantive offences and rules for increase of punishment) targeting organised crime (see for instance s. 198 on forming a group for serious organised crime, and s. $79 \mathrm{c}$, which increases the punishment for offences carried out as part of organised crime).

The criminal regulation of drugs is, as shown, quite harsh, at least by Norwegian standards. The rules include more or less all forms of involvement in drugs, apart from where this has a legitimate purpose (lawful medicine, evidence in courts etc.). An important aim is, as mentioned above, to target professional drug crimes/criminals. This has, of course, a spillover effect on less serious drug crimes. At the same time, there are some 'mitigating' aspects. These are either limitations on the scope of the criminal regulation, or 'constructive' elements within it. So-called 'syringe rooms' are an example of the former. These are particular areas (rooms) with healthcare personnel where long-time heroin abusers 
may use heroin without risking police intervention and criminal responsibility. ${ }^{16}$ As for the latter, the most notable element is rehabilitation from drug abuse as a particular aim of the sanctioning system. For instance, when a conditional prison sentence can be delivered, the judge has the opportunity to combine this with so-called 'drug-programme with court control' (in Norwegian, narkotikaprogram med domstolskontroll or ND), according to s. $37 \mathrm{f}$ of the Penal Code. This alternative, however, is not strictly limited to offenders who have committed drug offences. Rather, the ND-program targets offenders of drug-related crime with a manifest rehabilitation opportunity. Drug offenders may qualify for this reaction, as for instance in the Supreme Court case referred in HR-201701676-A. ${ }^{17}$ Furthermore, the Supreme Court, which in Norway has extensive influence on the practice of sentencing, has more generally given significant weight to rehabilitation considerations in sentencing, for instance when considering whether to apply an unconditional prison sentence or a community service sentence for offenders with a drug problem but with a potential for rehabilitation. Even gross drug offences may be punished with community sentence if clear and strong rehabilitation considerations ('klare og sterke rehabiliteringshensyn') call for it. ${ }^{18}$

16 See further Lov om ordning med lokaler for injeksjon av narkotika (sprøyteromsloven) av 2. juli $n r .64$ and the more detailed requirements for use of the syringe room in Forskrift om ordning med lokaler for injeksjon av narkotika (sprøyteromsforskriften) av 17. Desember 2004 nr. 1661. See further e.g. Andenæs and Andorsen 2007 pp. 252-557. Currently, the two largest cities in Norway, Oslo and Bergen, are the only two locations for such syringe rooms.

17 The offender was found guilty of a violation of s. 232 first part cfr. s. 231 first part (gross narcotic drugs offence) for receiving 100 litres GBL and for having sold or participated in selling at least 86 litres of GBL. He was sentenced to one year and seven months imprisonment, whereof the entire sentence was made conditional given that the ND-program was followed. The Supreme Court case concerned whether the full sentence or only a part of it should be unconditional. The verdict also describes the ND-program and its background more generally, see in particular sect. 8-16 in the verdict. In this regard, see also Rt. 2008 p. 1495 sect. 14 and 15.

18 Cfr. Rt. 2009.1045 sect. 9, with further references to Rt. 2005 p. 1312 sect 21, Rt. 2006 p. 1118 sect. 11 and 18, Rt. 2007 p. 950 sect. 13, Rt. 2007 p. 1244 sect. 12, Rt. 2009 p. 290 sect. 13 and Rt. 2009 p. 294 sect. 14. 


\section{International Obligations}

In order to grasp the Norwegian criminal regulation of drugs, and the debates in the preparatory works of this regulation in particular, the international perspective should be added. ${ }^{19}$ Norway is bound by several international conventions of relevance in this regard, and the criminal regulation of drugs in the Penal Code and in the Medicine Act is presumed to be in accordance with these international obligations.

The United Nations Single Convention on Narcotic Drugs of 1961, the Convention on Psychotropic Substances of 1971 and the Convention against Illicit Traffic in Narcotic Drugs and Psychotropic Substances of 1988, to which Norway is a party, form a central part of the international efforts to combat drug abuse and drug trafficking. While the Single Convention on Narcotic Drugs and the Convention on Psychotropic Substances aim to limit the use of drugs to certain scientific and medical purposes, the latter obliges the member states to take measures to combat the illicit trafficking of drugs. To achieve these purposes, article 36, subparagraph 1(a) of the Single Convention of Narcotic Drugs states that the parties shall make most types of involvement with drugs 'punishable offences when committed intentionally', and if these offences are serious, they must also be 'liable to adequate punishment particularly by imprisonment or other penalties of deprivation of liberty'. Unlike s. 24 of the Medicine Act, article 36 does not explicitly list a person's own use of drugs as a form of drug involvement that must be met with punitive responses. As is pointed out in the Commentary to the Convention, personal consumption of drugs does not constitute illicit traffic, which is what article 36 intends to combat. ${ }^{20}$

Article 36 does, however, require that intentional 'possession' of drugs is made punishable. There has been some doubt as to whether the term 'possession' only covers possession for distribution, in which case possession for personal consumption falls outside the scope of the article. ${ }^{21}$ If the answer to this question is affirmative, it means that s. 231 of the Penal Code, which covers oppbevaring, is sufficient to fulfil the requirement of criminalisation set out in article 36 . The Ministry of Justice touched on the subject in the preparatory works of the Penal Code. It was pointed out that the other alternatives list-

19 See in this regard in particular Bergersen Lind, Narkotikakonflikten (Gyldendal norsk forlag, 1976) pp. 18-29, who clarifies how the Norwegian criminal regulation of drugs early on was dominated by international solidarity and conventions, in particular the Hague- and Genevaconventions. Bergersen Lind concludes: 'Both in a short term and a long term perspective we had in reality abandoned full national sovereignty in defining the problem, understanding its causes and choice of line of response. Through legislation in 1913 and 1928 we formed our national legislation in terms of the Hague- and Geneva-conventions, and our future freedom of action was further reduced by the general slowness of the national legislation processes.' (p. 29).

20 Commentary on the Single Convention on Narcotic Drugs, 1961 (United Nations 1973) p. 428, para. 7.

$21 \quad$ Ibid., para. 8 and p. 402 , para. 2. 
ed in article 36 are of a more serious nature than possession for personal consumption, which spoke in favour of a more restrictive interpretation. A wide interpretation of the term 'possession' would also be more difficult to reconcile with the fact that use of drugs is not covered by article 36 , as the use of drugs presupposes some form of possession. ${ }^{22}$ The question was not elaborated further because the general prohibition against use and possession of drugs in the Medicine Act s. 24 was upheld. The Norwegian criminal regulation would therefore be compatible with the Convention of 1961, even if article 36 were to be understood as requiring criminalisation of possession for personal consumption.

Another relevant provision that was mentioned in the preparatory works of the Penal Code, was article 3, subparagraph 2 of the Convention of 1988. According to this article, intentional possession of drugs for personal consumption that is contrary to the 1961 Convention, the 1961 Convention as amended or the 1971 Convention, shall be established as a criminal offence. The wording of the provision is clearer than in the Convention of 1961, and the Ministry of Justice has therefore concluded that article 3 requires that possession for personal consumption is made punishable. However, in 2004 the International Narcotics Control Board (INCB) stated that Portugal's 'practice of exempting small quantities of drugs from criminal prosecution is consistent with the international drug control treaties. ${ }^{23}$ While minor possession is not legalised in Portugal, it is sanctioned by administrative regulations. The former President of the INCB has therefore also confirmed that all of the three drug control conventions leave room for the member states to provide alternatives to conviction and punishment in such cases. ${ }^{24}$

As mentioned in chapter 2, s. 24 of the Norwegian Medicine Act is limited to temporary possession of smaller quantities of drugs with the aim of (immediate) own use, while s. 231 of the Penal Code covers possession that involves larger quantities of drugs or possession for a longer period of time. This means that the Norwegian criminal legislation is in accordance with both article 36 of the Convention of 1961 and article 3 of the Convention of 1988. However, the acceptance of the Portuguese approach illustrates that alternatives to punitive responses can be consistent with the conventions. And as we will show below, some have argued that a similar approach should be followed in Norway.

Aside from the UN drug conventions, the EU's efforts to combat drug offences also form an important part of the international framework. The Council Framework Decision 2004/757/JHA of 25 October 2004 obliges the EU member states to make most forms of drug-related activities punishable when committed intentionally (see articles

Ot.prp. nr. 22 (2008-2009) p. 91.

INCB Annual Report 2004, para. 538.

See Sipp, 'The Portuguese Approach and the International Drug Control Conventions' (2015) at https://www.incb.org/documents/Speeches/Speeches2015/statement_reconvened_CND_side_ event_portugal.pdf (last accessed 21.03.18) pp. 3-4. 
2 and 3). ${ }^{25}$ The Framework Decision is clearer than the UN conventions regarding the question of criminalisation. Subsection 2 of article 2 explicitly states that drug offences that are committed by persons 'exclusively for their own personal consumption' fall outside its scope, which means that the states are not obliged to criminalise such acts in their national legislations. This is an important point, even though Norway is not a member of the EU and the Framework Decision is not EEA-relevant, and Norwegian authorities are therefore not bound by its guidelines. ${ }^{26}$

\section{The Criminalization Issue}

\subsection{Purpose of this Section}

The question now is the normative basis for the Norwegian criminal regulation of drugs. We will here outline the debates on the subject and add some of our own reflections. As we shall see, this is not only a debate in its own right in Norway. The debate reflects also a not sufficiently worked out theoretical basis for such debates generally.

\subsection{The Preceding Debates}

The discrepancy between the (defensive) Nordic criminal law culture and the offensive drug criminal policy and regulation is well captured by Per Ole Träskman, whose extensive knowledge of the different Nordic countries led him to the following conclusion: ' $B u t$ for drug policy we can observe a quite opposite attitude. Drugs must be strongly combated, and the means are primarily penal. ${ }^{27}$ This uncompromising attitude to drugs has been widely shared in Norwegian politics. However, critical voices have been raised as well. The most significant academic critique stems from criminologists. Already in 1976, Brit Bergersen Lind subjected both the origin and empirical basis of the Norwegian crimi-

25 The framework decision also lays down mimimum penalties for such offences in article 4.

26 In the preparatory works of the Penal Code, the Ministry of Justice stated that it was natural to look to these guidelines even though they are not binding, see Ot.prp. nr. 22 (2008-2009) p. 96. For a general discussion on the influence that EU law has on Norwegian criminal law, see e.g. Jacobsen, 'Om EU-strafferettens innverknad på norsk alminneleg strafferett', Tidsskrift for strafferett (2015) pp. 428-446, and also other contributions to the same publication.

27 Träskman, 'Drug Control and Drug Offences in the Nordic Countries: A Criminal Political Failure too often Interpreted as a Success', 5 (2) Journal of Scandinavian Studies in Criminology and Crime Prevention (2005) pp. 236-256, pp. 236-237, DOI: 10.1080/14043850410010739. See also from the same author, 'The Dragon's Egg - Drugs-related Crime Control', in Snare (ed.), Beware of Punishment. On the Utility and Futility of Criminal Law. Scandinavian Studies in Criminology 14 (1995) pp. 147-172. On the notions of 'offensive' and 'defensive' criminal policy, see in particular Jareborg, 'What Kind of Criminal Law Do We Want?' in Snare (1995) pp. 17-36. 
nal regulation of drugs to a critical analysis in Narkotikakonflikten - Stoffbruk og myndighetskontroll ('The Drug Conflict - Drug Use and Governmental Control'). ${ }^{28}$ The most well-known critic has however been Nils Christie (1928-2015), who, together with his Finnish colleague Kettil Bruun (1924-1985), criticised the drug policy in particular in the book Den gode fiende ('The Good Enemy'). ${ }^{29}$ It was first published in 1985, the very year that Bruun passed away. After this, Christie was responsible for two more editions (1995 and 2003), before he himself passed away in 2015. In this book, the entire 'war on drugs'-regime was subject to critique in light of classical sociological perspectives on society, deviance, power and control. A third critic is criminologist Ragnar Hauge, who for years has worked on criminal law and issues concerning drugs, alcohol and related phenomena. Hauge was also a member of the majority of the Criminal law commission who suggested significant changes in the criminal regulation of drugs (see further below). ${ }^{30}$

Critical voices have also been raised within the legal profession. Just after the second edition of Christie and Bruun's book was published, the most influential Norwegian criminal law scholar in the second part of the $20^{\text {th }}$ century, Johs. Andenæs (1912-2003), published his Straffen som problem ('Punishment as a Problem'). This book contained his reflections over a number of central criminal law issues, including the criminal regulation of drugs. Here, Andenæs described the field of drug offences as 'the perhaps most troublesome area of criminal policy in recent years. ${ }^{31}$ Instead of 'war on drugs', Andenæs found it more reasonable to aim for minimising the total damage of drugs in our society. ${ }^{32}$ The war on drugs-approach was a product of our 'moral indignation over drugs.. ${ }^{33}$ His attack on the criminalisation was directed at (use of) cannabis, which had only a 'weak' basis. ${ }^{34}$

Whereas in particular Christie's fundamental critique concerned the entire control system related to drugs and its social implications, the most recent debates have mainly concerned legalisation of (minor) possession and use of (at least some types of) drugs. This was, for instance, a topic for the Criminal law commission in its work with the Penal Code of 2005. A significant part of this work was the commission's general adoption of a harm principle as the starting point for the criminalisation issue. ${ }^{35}$ This was a new approach to criminalisation in Norwegian criminal law, which is something of a para-

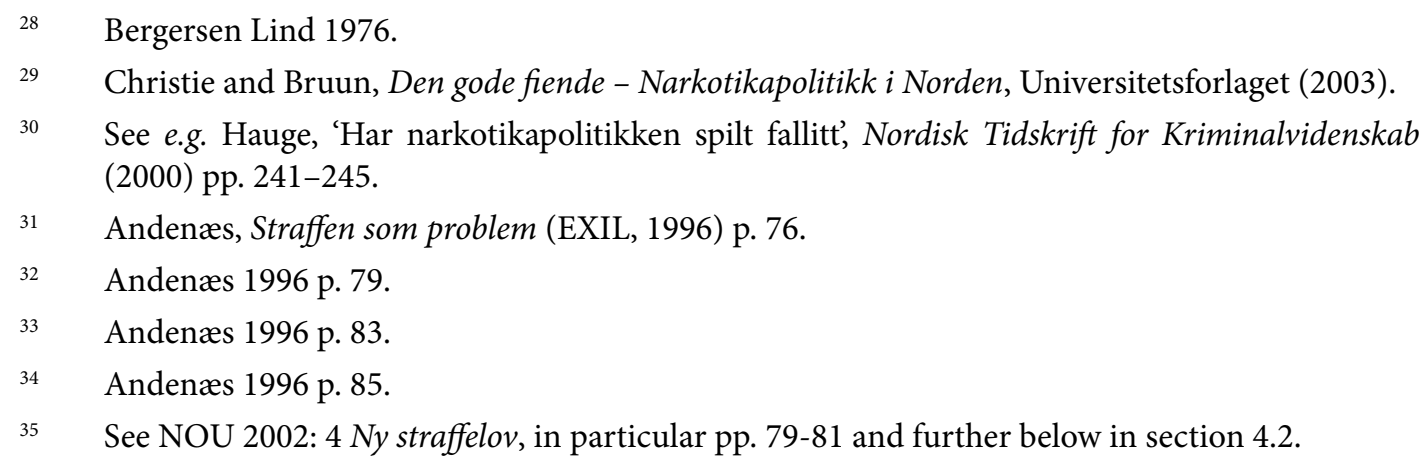


dox: The academic critique was dominated by pragmatic criminal policy considerations, while the legislator adopted the more principled approach to the criminalisation issue. ${ }^{36}$ This approach was also contrary to the clearly pragmatic reasoning that had dominated previous Norwegian criminal legislation. ${ }^{37}$ We will get back to the more general aspects of this reasoning. The central point here is that this approach also influenced on the commission's reasoning on the drug issue. In fact, the drug issue was addressed in the general remarks on the harm principle. ${ }^{38}$

\subsection{The Drug Problem in the Preparatory Works}

In NOU 2002: 4 a majority argued for the decriminalisation of use and possession for use of drugs. ${ }^{39}$ The reason for this conclusion was twofold: First, the majority argued that the main purpose of criminalisation is to combat acts that cause harm to others and not only to the person who commits the act. And because the use of drugs only directly affects the drug user, drugs should be handled in the same manner as other forms of addictive substances, such as alcohol and tobacco. The harm principle could therefore not justify criminalisation. Second, humane considerations were also considered to speak in favour of decriminalisation in cases involving long-term drug addiction, which is often linked to other personal or social issues. The majority did stress the importance of police control of drug environments, but did not see this as standing in the way of decriminalisation of purchase for own use. Rather, the spread of drugs should be controlled by means of health/social policy instruments.

The minority did not support the majority's proposal to repeal the Medicine Act ss. 24 and 31, and thereby decriminalise use and possession for use. ${ }^{40}$ The minority argued that decriminalisation would send the wrong signals to younger persons with regard to drug use and that the general importance of combatting the spread of drugs also spoke in favour of continued criminalisation. And, contrary to the majority's view, the fact that

36 The commission's adoption of the harm principle was followed up by both the Minstry and the Parliament, albeit with certain modifications. See Ot.prp. nr. 90 (2003-2004) pp. 82-93, Innst. O. nr. 72 (2004-2005) pp. 16-17 and further below. The approach applied by for instance Andenæs in this discussion corresponds, however, to the traditional approach in Norwegian criminal law science, see further Jacobsen, 'The Methodology of the Norwegian Criminal Law Doctrine', in Elholm et al. (ed.), Liber amicarum et amicorum Karin Cornils - Glimt af nordisk straffrätt og straffeprosessrett (DJØF, 2010), pp. 243-266.

37 See however NOU 1985: 19 pp. 28-30, where the principle is applied to pornography. Here, the criminalisation of drug use was mentioned as an example of paternalism in crimininal law, but not in a critical sense.

$38 \quad$ See NOU 2002: 4 pp. 80-81.

$39 \quad$ NOU 2002: 4 pp. 330-331.

40 Ibid., pp. 331-332. 
other addictive substances were legal under Norwegian law was considered an argument against legalising another one. The minority did not discuss if, or to what extent, the harm principle could justify continued criminalisation of such acts.

The minority view was supported by the Sanctioning commission. This commission was to consider alternative sanctioning systems for certain administrative offences in particular, and worked more or less parallel with (but was not part of) the Criminal law commission. ${ }^{41}$ The Sanctioning commission formed five separate but closely connected criteria for criminalisation. ${ }^{42}$ The first criterion to be considered is if it is necessary to sanction an act, and, if yes, if this sanction must come in the form of punishment. The second criterion represents a continuation of the latter part of the first criterion: When considering if the response must have a punitive character, it is necessary to answer if the same goal can be achieved by other means - punishment should be a subsidiary sanction. The third criterion is also closely related to the question of whether it is necessary to apply penal measures, but focuses on the negative effects of the act in question. The question is therefore if the protected interests that are affected by the act, whether they are public or private, are sufficiently important to justify the use of punishment. The fourth criterion is called the qualification criterion because it raises the question of the severity of the act, and indicates that punishment should be reserved for more serious offences. These four criteria reflect central aspects of the harm principle. The fifth and last criterion focuses not on the act in itself, but on the responses to it. An act should only be criminalised if the sanction will be enforced in practice.

The commission found involvement in drugs to be so serious that the qualification criterion for punishment was satisfied, and did not recommend decriminalisation or the replacement of punishment with an administrative fine. ${ }^{43}$ However, despite there being five criteria, only one of them was mentioned (but not discussed further) by the commission in regard to the question of decriminalisation of use and possession of smaller amounts of drugs. This is surprising, not only because it is far from clear that the criteria are satisfied in such cases, but also because a main point in the mandate was to reduce the use of punitive measures. It should be noted that the Sanction commission's approach to the subject may reflect more general problems with the way the commission formed its set of criteria for criminalisation. This entails, however, a discussion on its own, which we will refrain from here.

The Ministry of Justice took the same stance as the Sanctioning commission and the minority in the Criminal law commission when it reviewed the proposal made by the Criminal law commission. ${ }^{44}$ The proposal by the commission's majority was subject to

$41 \quad$ See NOU 2003: 15 Fra bot til bedring.

42 Ibid., pp. 143-147.

$43 \quad$ See NOU 2003: 15 p. 268.

44 Ot.prp. nr. 22 (2008-2009) pp. 90 ff. 
critique on several grounds. The Ministry of Justice did not agree with what it deemed to be a narrow understanding of the harm principle. It was held that the indirect harmful effects of an act also constitute a part of the principle, and that one had to consider the impact that drug use has on the user's family and social environment, the national economy and the general safety. The Ministry especially pointed to the risk of an increase in drug trafficking and in offences that help finance drug use, social problems and general unsafety as weighty arguments against decriminalisation. It is not clear if any of these would satisfy the qualification criterion for punishment if viewed separately, but in sum the negative effects were considered sufficient to meet the requirements of the harm principle, and thereby justify continued criminalisation.

In addition to the harm principle, the Ministry's conclusion to not decriminalise the use of drugs was based on the view that drugs stand in a different position from other addictive substances both historically and culturally, that decriminalisation can have a negative signalling effect, that criminalisation contributes to general deterrence and reflects fundamental societal values, and that drug offences committed by persons who struggle with long-term addiction are often not prosecuted by the authorities in practice. ${ }^{45} \mathrm{In}$ stead, the Ministry wanted more of 'reaction in the form of treatment' and more use of community service as punishment for less serious drug offences. ${ }^{46}$

This conclusion has not prevented the subject from being continuously debated in recent years. Both columnists and academics have advocated a renewed approach to drugs in Norway. ${ }^{47}$ This debate has, however, not managed to penetrate deeper into the principled dimensions of the current legislation. The Norwegian debate on the use/possession-issue has, as shown, been centred on policy-arguments, and thereby also on certain empirical premises that seem hard to put to the ground, leaving the debate in a deadlock. We do not deny the relevance of the social effects of criminalisation in this debate. However, when the discussion has turned to these matters, a number of choices and presuppositions are made concerning which arguments are relevant and what bearing they have on, for instance, criminalisation of drug use. Thus, there is a significant risk that the debate is already on the wrong track. The harm principle adopted by the commission may offer a lifeline for this debate. The reasoning in the preparatory works and its engagement of the harm principle remains the most profound theoretical enterprise in this context. In order to bring this debate further, it seems apt to have a closer look at this reasoning.

$45 \quad$ Ibid., p. 94.

46 Ibid., p. 93.

47 For one of several examples, see Johansen, 'Kriminalisering av narkotika er ikke-politikk', http:// www.jus.uio.no/ikrs/tjenester/kunnskap/kriminalpolitikk/aktuelt/legalisering-eller-politistat. html (last accessed 21.03.18). 


\subsection{General Remarks on the Discussion in the Preparatory Works}

The differing views in the preparatory works reflect some uncertainty in regard to how the harm principle shall be concretised both generally, in order to function as a kind of guiding principle in more concrete matters, and specifically in the context of drug use and possession. This debate may therefore be said to mirror more fundamental problems with such general principles and the operationalisation of these.

The use of criminalisation principles in the preparatory works has in this regard been criticised by Thomas Frøberg in particular. ${ }^{48}$ His argument is, basically, that while such principles may give a valuable contribution to debates on criminalisation by clarifying the argument and the relevant values, the principles applied by the Criminal law commission were inadequate. These principles may, according to Frøberg, even function to conceal the arguments that the legislator actually gives weight to, and hence make criminalisation decisions, contrary to the purpose of criminalisation principles, less transparent.

We share the opinion that the principles adopted by the legislator were insufficiently developed to adequately function as guidelines for criminalisation decisions. The discussion of the drug issue is, as we shall see, one example of this. It is, so to speak, not possible to solve the theoretical gap in Norwegian criminal law simply by infusing some (proposed) principled starting points into the discipline. On the contrary, even in legal cultures with a strong theoretical tradition, it has proved difficult to develop criminalisation principles that function in the desired manner. The (content of the) harm principle, 
for instance, has been subject to vivid debate. ${ }^{49}$ Nonetheless, one could certainly have achieved more than what was done in the preparatory works in Norway, for instance in regard to clarifying inadequate interpretations of these principles and the arguments related to them. One should not underestimate the rationalising effect that such principles may have on concrete argumentation. What is called for, is first and foremost more theoretical work on these principles, which can offer the legislator models of application to choose between. One may, for instance, make clear which more general accounts of the principle that one opts for and problems related to this. ${ }^{50}$ By approaching criminal law as a means to identify, secure and balance different persons' freedom spheres, we may also achieve a more fruitful basis for sketching out adequate criminalisation principles. ${ }^{51}$

As concerns Frøberg's claim that the principles may have the undesirable effect of a 'dishonest' legislator, this is certainly a possibility that should not be dismissed out of hand. However, the weakness of the argument becomes evident if we generalise it: If this fear of a dishonest legislator was generally applied as a reason not to search for different kinds of intellectual structures that can rationalise the use of power in settings such as legislation, very much of the project of the democratic Rechtsstaat seems to be threatened. So, we must remain faithful that even if there is such a risk, such argumentative standards

49 For an overview and discussion on the debate on the harm principle and its relation to other criminalisation approaches in Continental criminal law theory, see Peršak, Criminalising Harmful Conduct - The Harm Principle, its Limits and Continental Counterparts (Springer, 2007), who also defends the principle. See in this regard also for instance Simester and von Hirsch, Crimes, Harms, and Wrongs: On the Principles of Criminalisation (OUP 2011). As these works illustrate, however, the harm principle is often supplemented by an offence-principle, and possibly also other principles; see here for a critical review of the last mentioned work, StantonIfe, 'What is the Harm Principle For?', Criminal Law and Philosophy 10 (2) (2016) pp. 329-353. Some have suggested that we should go beyond the harm principle, see for instance Ripstein, 'Beyond the Harm Principle', Philosophy \& Public Affairs, 34 (3) (2006) pp. 215-245. Others have advocated a rethinking of the idea of one harm principle, see e.g. Duff and Marshall, "Abstract Endangerment", Two Harm Principles, and Two Routes to Criminalisation', Bergen Journal of Criminal Law and Criminal Justice 3 (2) (2015) pp. 131-161 (including comments to similar approaches at pp. $136 \mathrm{ff})$. Harcourt describes for his part the empowerment of the harm principle (as it has developed) as a critical principle, cfr. Harcourt, 'The Collapse of the Harm Principle', Journal of Criminal Law and Criminology, 90 (1) (1999) pp. 109-194, in particular p. 113. The harm principle has also been subject to similar critical appraisals from Nordic scholars, see in particular Lernestedt, Kriminalisering - Problem och principer (Iustus, 2003) pp. $181 \mathrm{ff}$. See also Hortug, 'The Harm Principle', Ethical Theory and Moral Practice 5 (4) (2002) pp. 357-389 DOI: https://doi.org/10.1023/A:1021328520077. Most of these works refer in one way or another to the fundamental works in this debate, i.e. Mill's On Liberty from 1859 (reprint, Penguin books, 1985) and, more recent, Feinberg's four volume work The Moral Limits of the Criminal Law, consisting of Harm to Others (1987), Harmless Wrongdoing (1990), Harm to Self (1989) and Offense to Others (1987). Some of the works also touch upon the drug challenge, see for instance Harcourt 1999 pp. 172 ff.

50 See for instance Hortug 2002.

51 See for instance Gröning, Husabø and Jacobsen 2016 pp. 44 ff. 
will over time rationalise the use of power. Even if such principles may be bypassed by rhetorical moves, such moves may in turn be critically scrutinised and challenged. Regardless of the controversies concerning the precise interpretation of the harm principle, it gives at least an officially sanctioned starting point and some structure to debates concerning criminalisation. This is useful as as an entry point to scrutinise argumentation.

Certainly, there are challenges to the harm principle, and it is not even clear that this is the most promising candidate for a guiding principle for criminalisation in Norwegian criminal law. Hortug presents a central challenge in this regard: ${ }^{52}$

The point is not just that the issue of coercion must be settled by appeal to a more general moral theory. Since we are trying to derive the Harm Principle from such a theory, this is hardly surprising. Rather, the point is that the Harm Principle cannot even be applied in particular cases without considerable knowledge of the theory of justice being applied. So the Harm Principle is of no use without a theory of justice, but if we have this theory, it seems that we have no need for the Harm Principle. It would seem that the theory of justice will settle the issue of coercion all by itself.

How should we then proceed? One alternative is to rework the harm principle for a more solid conception of it than what is offered in the preparatory works, which is a called for task for the Norwegian criminal law science. This article is, however, not suited for this kind of enterprise. Even a rehearsal of the extensive literature on the subject would be an immense undertaking. A more limited enterprise would be to consider only literature that concerns the drug criminalisation issue..$^{53}$ But even this would go beyond what this article allows for. Here, we will limit ourselves to a more restricted enterprise: We will adopt a (narrow or, if one prefers, positivistic) coherence perspective: We will consider whether the contemporary criminal regulation of drugs and its justification in the preparatory works are coherent with the principles embedded in Norwegian criminal law. Even if this body of law is not consistently designed from these principles, they express the normative commitments of the legislator. The adoption of a harm principle may be read as an attempt to 'bring to the surface' viewpoints deeply embedded in Norwegian criminal law. Given this, we may by way of adopting a coherence perspective, bring more structure to the understanding of the harm principle and its application to the drug issue. The following remarks are contributions to this kind of exercise. This is, however, only a supplement to, or a kind of preparation for, a theoretical elaboration of the harm principle (or its equivalent).

The central focus will be on the criminalisation of drug use and (minor) possession, but we will not strictly limit ourselves to this question. Furthermore, as a starting point,

$52 \quad$ Hortug 2002 p. 386.

53 See for instance Husak's works on the subject, for references see Husak 2018 in this volume. 
we are mainly dealing with the mildest forms of drugs, such as hashish. We will consider three potential harm-perspectives, or aspects visible in the debates in Norway, which are the following: 1) harm to the user him-/herself, 2) harm in the market, and 3) harm to others in the aftermath of the use. In each regard, we will consider whether there is (from the above mentioned coherence perspective) a relevant harm, and also consider whether criminalisation is needed in order to avoid the relevant harm. As we shall see, this gives us reasons to question whether the legislator has sufficiently justified the current criminalisation of minor possession and use of drugs. We ask the reader, however, to keep in mind that our aim is to press the arguments in order to improve the discussion on this subject, not to advocate one particular position in it.

\subsection{The Harm to Oneself-Perspective}

Drug use, and drug addiction in particular, is often claimed to be related to a series of negative effects for the individual. Drug addiction is often associated with reduced cognitive and physical abilities, the inability to work, poverty, and an exposed social position in general. We bypass here the empirical basis for claiming that these problems frequently follow from drug use, and accept this as a premise. (If the premise is challenged, this will only further weaken the argument for criminalisation). The question is, then, whether such negative consequences suffice to justify the extensive criminalisation of drugs, a problem often discussed in terms of 'harm to oneself'. Negative effects to others, such as family, are not taken into consideration for now.

The limited role of the harm to oneself-argument in criminalisation can be explained by the fact that the Norwegian criminal law, as a basic starting point, is concerned with securing the freedom of the individual. ${ }^{54}$ Interpreted from a 'Kantian' point of view, we may say that there are reciprocal freedom spheres that make claims for respect, i.e. non-intervention. It is the purpose of the criminal law to (contribute to) concretise these freedom spheres, in the sense of identifying their more precise scope, reacting to violations of them and also preventing others from intruding into the freedom spheres of their fellow citizens. ${ }^{55}$ This calls for acts to have a negative impact on someone's (free exercise of their) freedom sphere, i.e. (some kind of) harm to others, for criminalisation to be a relevant means. Hence, harm only to oneself does not warrant criminalisation.

However, the broad notions of 'harm to oneself' and 'harm to others' call for nuances. It is evident that the limits of criminalisation should run along more complicated lines than this distinction offers. We must, for instance, separate between different meanings,

54 For a elaboration of this starting point, see for instance Jacobsen, Fragment til forståing av den rettsstatlege strafferetten (Fagbokforlaget, 2009), pp. $401 \mathrm{ff}$.

55 See Gröning, Husabø and Jacobsen 2016, chp. 2. 
or extensions, of 'harm to oneself'. The first meaning is that one harms oneself, and only oneself, i.e. that one's act damages one's private interests exclusively. For instance, Jane has an old book, which no one else has a stake in, and she chooses to put it into the fireplace, in order to heat up the cabin. If this is also an adequate account of drug use, it should be clear that the harm to oneself-perspective does not warrant criminalisation. However, harm to oneself is not always exclusively a private matter, even if it is the individual user who is directly affected by it. Rather, sometimes it is a public matter, i.e. a matter of harm to oneself that also goes beyond oneself.

This subject may in turn be said to have two dimensions. There is the classical harm to others-perspective, which we will return to below, where we will address consequences of drug use to family and society in general. The other dimension, which we will address here, is in a sense more foundational. It concerns acts to oneself that somehow undercuts one's ability to fulfil the demands of public reason, i.e. to fill the role of being a person. This can be considered a fundamental democratic duty for each of us. We shall consider whether drug use, and the inherent risk for addiction in particular, is in itself a reason to criminalise the act from this perspective. In order to do so, we must clarify this protection of the person role-principle. The principle is most usually discussed in terms of (the limits of) consent, where one distinguishes between 'disposable' and 'non-disposable' dimensions of one's freedom. ${ }^{56}$ When harm to others is the result of the other's own decision, i.e. by consent, this does not have the meaning of a violation, and is in many instances not considered an act type relevant for criminalisation. For instance, one is clearly free to limit one's own freedom in terms of subjecting oneself by consent to an employer's orders, so that one becomes locked in at a certain facility, or prevented from leaving a certain geographical area, for some time. Generally, we are to a high degree (legally) competent to use both our body and property in the way that pleases us. The free exercise of one's freedom sphere in terms of consent is, however, to some extent restrained. Such restrains can in particular be found in regard to certain acts where the individual rules precisely over this status as a free (and responsible) member of the political order. Slavery, for instance, is prohibited by the Constitution and is also punishable (see s. 259 of the Penal Code), so one cannot subject oneself to slavery. Furthermore, although one can consent to take part in a fight, even where this entails harmful consequences (see further s. 276 first part), one cannot, according to Norwegian criminal law, subject oneself to severe bodily harm punishable by s. 274 second part. ${ }^{57}$ Hence, there are certain limits as to what one can subject oneself to when the given act would somehow jeopardise one's ability to fulfil the role of a citizen, limits that protect one's more fundamental status as a person.

This distinction between 'disposable' and 'non-disposable' dimensions of one's freedom may seem applicable to drug use, at least in cases where there is a risk for addic-

56 See Gröning, Husabø and Jacobsen 2016 pp. 214 ff.

$57 \quad$ See for instance Matningsdal 2017 pp. 615 ff. 
tion. The problem is, however, that the scope of the offences in the Penal Code seems to express a more limited conception of the extent to which this point of view may justify criminalisation. To see this, we may add another accentuation of 'harm to oneself', i.e. one that emphasises that it is oneself that does the actual harm. All of the offences mentioned where there are limitations on consent concerns acts performed by others. Acts that harm oneself and are performed by oneself are generally not subject to criminal responsibility. A more detailed study shows that this it is a general principle of Norwegian criminal law. ${ }^{58}$ Suicide, for instance, is not an offence, nor attempts at suicide (contributing to the suicide of others, however, is punishable cfr. s. 277). As concerns the drug user (abuser), this principle clearly indicates that harms to oneself, performed by oneself, should not be subject to criminalisation, even when the act undercuts one's ability to fulfil one's role as a citizen. Hence, criminalisation of minor possession and use of drugs can only be supported by making an exception to the mentioned harm to oneself-principle, in favour of a kind of paternalism (concern for the individual). The Criminal law commission was open to a paternalistic justification in some cases. It may be that the most direct strategy is precisely to acknowledge a supplementary paternalism principle. As we will see below, this may correspond to certain traits of the Norwegian criminal law, so it would not be fully far-fetched to at least consider the possibilities for such a supplementary principle. However, to justify this kind of paternalism principle in light of the more fundamental traits of Norwegian criminal law is a different and, we believe, far more difficult matter.

It seems here apt to depart a bit from the criminalisation of use, and consider sales to the user and similar acts. Judging from the foregoing remarks, it seems at least reasonable to consider the contribution of others to a specific person's drug abuse as a blameworthy type of act that merits criminalisation, for instance production and sales of drugs. However, at a principled level, this only concerns situations where there are significant negative effects to the individual, i.e. harm relevant to the person status, at stake. As mentioned, contribution to other's lesser harm to themselves is considered legal from the point of view of the Norwegian criminal law. This harm to oneself-perspective thereby only warrants criminalisation where the buyer/user either is a drug abuser or is in danger of becoming one. Only then can we say that one profits on someone else's misfortune, so to speak. This indicates that, in this perspective, sales of lesser units of drugs to someone in control of their drug use, cannot be considered a blameworthy act in itself. A parallel can here be made to the decision on consent to violations of the body in the Supreme Court case referred in Rt. 2004 p. 849. The case concerned whether a 15-year old girl was able to consent to being injected with amphetamine by two older males, or whether the injection was punishable as a violation of the body (s. 228 of the previous Penal Code of 1902). The Supreme Court held that s. 235 of the (previous) code, according to which violations of the body were not punishable if consent was given to such acts, could not be 
interpreted so as to require that there is a justifiable reason for the consent. As long as the consenting person understood the character of the act, its consequences included, a valid consent had been given. The Supreme Court concluded that the girl understood what she had consented to, and the injections were therefore not deemed to be punishable. From this point of view, then, the position of the Norwegian Penal Code seems to be that drug use per se is within legitimate exercise of the individual.

One way out is to limit the criminal responsibility of sales to sales of larger quantities, or to sales of for instance 'bad' drugs, where either the type of drug itself or (only) the relevant sample of it, is harmful to the (unknowing) purchaser/user. A different solution would be to restrict the criminalisation of selling drugs to situations where the user is a drug addict or is in danger of becoming one. In the first case, selling drugs to the individual contributes to upholding the addiction; in the second case, it may possibly contribute to addiction in itself. The (practical) problems related to an offence delimited in this way, are, however, obvious. A different way out, then, is to claim that every drug user risks addiction and thereby also deprivation of their capacity for being a free and responsible individual.

This brings to the foreground an underlying concern that motivates the Norwegian criminal regulation of drugs, which is of general relevance to the subject. The subject at stake is this: What to expect of one's citizens? The Norwegian legal culture is a liberal legal culture. However, Norway is also a welfare state, where the state for a long time has been concerned with the individual's health and wellbeing. There is a tension between these liberal and paternalistic ideas, depending partly on what conceptions of the individual that the paternalistic considerations rely on. In this regard, it seems fair to say that the Norwegian legal culture reflects a certain distrust of its citizens. Alcohol, for instance, has generally been severely regulated in Norway. This is reflected in the rules of criminal responsibility for alcohol-related acts, where (a lacking) intent is constructed where its absence is due to (willed) intoxication. ${ }^{59}$ The state has also shown a great concern with regulating acts such as the consumption of pornography. It was only following a Supreme Court judgement in 2005 that the consumption of non-censured pornography became legal in Norway, many years later than in the other Nordic countries. ${ }^{60}$

It does indeed seem fair to claim that this distrust reflects itself in the contemporary Norwegian criminal regulation of drug use: The opinion of the state seems simply to be that its citizens cannot handle drugs, alcohol, pornography and similar vices that can (and hence will) lead to excessive use and corruption of the individual, with negative consequences also for others. It is, however, also fair to question whether this 'picture' of its citizens is a fair one for a liberal state to have and to act upon. This question is especially

59 See also Gröning and Myklebust, 'Intoxication and Self-Induced Criminal Incapacity in Norwegian Law' in this volume.

$60 \quad$ Rt. 2005 p. 1628. 
important when such a picture leads not only to strict regulations but also to the criminalisation of acts with a less clear (causal) relation to harm. This is a very fundamental and many-sided subject, with historical and philosophical aspects, which we shall not dig further into here. Its relevance for the Norwegian debate on the criminalisation of drug use can, however, hardly be overstated.

It is also important to note that such a far-reaching concern for the potential of each individual user to become an addict, is not reflected in the mentioned Supreme Court decision. If the use of amphetamine in itself implies a significant risk of person-deprivation, it is hard to see that a 15-year old girl, or any individual for that sake, should be able to consent to it. It is also worth adding that, in a recent judgment, the Supreme Court took into account the risks connected with the use of LSD when addressing the scope of punishment for LSD-related offences. The Supreme Court significantly lowered the sentencing level for involvement with this drug, based on the following considerations: ${ }^{61}$

\begin{abstract}
The risk of addiction is small, and the risk of a lethal overdose is minimal. The risk of health damage and other somatic harms is also small. Such risks are, moreover, primarily connected with [the individual's] conduct during intoxication, and primarily affects only the user himself. As for the long-term psychological effects [of the drug], both the existence, frequency and causal relation [of such effects] are unclear. ... Generally speaking, LSD is a drug that has the potential to cause both addiction and health damage, but since it is a drug that few people use, that is seldom used, and the side effects of which are at any rate rare, it is difficult to map out the possible side effects and their cause by means of scientific studies.
\end{abstract}

Considerations like these call for additional arguments to be made, in order to criminalise for instance the act of selling drugs to an individual. ${ }^{62}$

So far, we have seen that the harm to oneself-perspective hardly offers a good reason to criminalise the use of drugs or the selling of drugs to drug users. A kind of paternalism principle would be required in order to justify criminalisation in such cases. If we want to stay faithful to the harm principle, we should look for other kinds of harms, to others, related to drug use. These kinds of harm could (logically) be related to the use itself either as a precursor to the use or as a causal effect of the use. To begin with, one fruitful line of argument could be that the state has an interest in regulating the market, in order to avoid both harm to individuals from bad drugs and the kind of violations that are often associated with illegal drug markets prior to the use itself. We will now turn to this perspective. Court and concurrs to this.

62 See also Holmøyvik, 'Dop i domstolane', Agenda Magasin (23.09.17) at https://agendamagasin. no/kommentarer/dop-i-domstolane/ (last accessed 21.03.18). 


\subsection{The Harm in Drug Markets-Perspective}

It is a widely shared conception that drugs often have their origin in countries where the drug trade is connected to violence and murders, mafia activity, corruption and more, and that these problems also make their way into the distribution systems. The smuggling of drugs to for instance Europe (Norway included) is often related to the same kind of activities. Violence also occurs in connection with competition between different distributors of drugs, and practices such as debt collection. This violence is not restricted to those participating actively in the system. It can also strike at, for instance, innocent victims of a drive-by shooting, or family members that are threatened to get at an active participant. Furthermore, the quality of the drugs exchanged in this market vary, and a general problem is the lack consumer information: Producers and distributors are usually required to inform the consumers about the contents of, and risks related to use of, their products. Clearly, drug distributors do not seem to do this. Also, the drug market is likely to lack mechanisms for controlling who purchases the products, and sales to vulnerable individuals, such as children and addicts, are known to occur. For simplification, we will call considerations of this kind the harm in drug markets-perspective.

Given that these market deficiencies are actual, and in particular if it is fair to describe the drug distribution system as a genuine 'violent system', it seems fair to say that participants in this market, more or less regardless of the specific roles they play, are blameworthy for contributing to the harm of others. Several of the acts punishable as drug offences may by this line of reasoning legitimately be criminalised. At the end of the line, however, we must consider whether the fact that drug users (who purchase, possess and use drugs for their own pleasure) are blameworthy for contributing (financially) to a harmful market, and therefore legitimately subject to criminal responsibility. Here, we should keep in mind that it was part of the proposal of the majority of the Criminal law commission to also decriminalise the purchase of drugs for personal use.

This seems to be a promising line of reasoning for those who want to defend the extensive existing criminal regulation. It seems fair to blame anyone who contributes to this kind of market, even if the amount of blame may differ between different kinds of participation in it. This line of reasoning seems also to fit into the harm to others-category: One gives support and incentives to a system that in many regards has a clear negative impact on the lives of other individuals. This seems also to be consistent with the general principles of Norwegian criminal law, which criminalise acts that contribute to other kinds of criminality, even if the contribution takes place after the relevant crime has been performed. Examples can be found several places in the Penal Code, especially in the provisions concerning economic crimes. One practical example is s. 332, which criminalises any act that consists of benefitting from a criminal offence, typically by buying or being in possession of stolen goods. Another example is s. 337, which criminalises the in- 
volvement with proceeds from criminal activity, either by safeguarding such proceeds or by concealing its illegitimate origins (money laundering). Both intentional and negligent acts are punishable in such cases. ${ }^{63}$

Although the need to prevent and sanction acts that contribute to the continued existence of this kind of drug market seems evident, the argument has its limitations. First, it can be questioned if this line of reasoning provides an argument for criminalising the use of drugs or possession for own use. It is first and foremost the purchasing of drugs that contributes to the production, smuggling and marketing of drugs. One can also consider a kind of de minimis demarcation of a criminalisation justified by such viewpoints. These arguments may perhaps be countered by the fact that criminal responsibility for handling stolen goods also covers use, consumption and similar handling of such goods. ${ }^{64}$ Use of the drug is also likely to cause, or at least increase the possibility of, future purchases. Secondly, the state is in control of one very efficient option that gives its citizens an alternative to contributing to the market, i.e. to offer a legal alternative for purchasing certain drugs, similar to how the Norwegian authorities have dealt with alcohol. This kind of arrangement may give the state particularly good reasons to criminalise contributions to the illegal drug market, as the citizens have an alternative to being part of it. One possible response, that at least merits closer attention, is however, to say that it is not in the interest of the state to offer a legal alternative, and as long as this is the case, one is not allowed to contribute to an unwanted, harmful market. However, it is at least worth reminding of the fact that the state here seems to be involved in a negative loop, as the war on drugs seems to be a central factor behind this illegal market. A third argument is that this harm in the market does not give good reason to criminalise purchase, sales, or even production of drugs, where this takes place in 'controlled' forms, that is with no connection to the mentioned drug market: A grows weed in her own apartment, uses some of it, and sells some of it to B, who purchases it for recreational use for himself and his friends C and D, all 25-year-old, sane individuals in control of their use of this drug. The harm in the market-perspective does not seem to justify the criminalisation of this kind of involvement in drugs. Judging from these remarks, it seems as if the harm in the market-point of view opens for a more nuanced set of both arguments and solutions, and these arguments ought to be explored further.

\subsection{Harm to Others in the Aftermath of the Use}

What then about the (causal) consequences of drug use, not for the user herself, but for others, that is, her family and friends, her children and the society at large? Here, there seem to be four different potential problems that need to be addressed: the emotional

\footnotetext{
63 See the Penal Code ss. 332 and 340.

$64 \quad$ See further for instance Rt. 1999 p. 386.
} 
concern of family and friends, the social costs related to drug abuse (expenses connected to health care services and similar), the signalling effect, and finally, the crime generative effect of drug abuse. These are not strictly separated from each other, but nevertheless deserve to be discussed separately.

To begin with, 'personal' harms such as emotional distress to family, friends and others, seems in general to be a weak argument: There are also a number of other acts and/ or ways of life that cause trouble to those near to us. Alcohol abuse, anorexia and other eating disorders, adultery, prostitution, school drop out, and converting to a fundamentalist religion may all generate enormous concern for family and friends. The general principle is that in human relationships there is an existential risk of being troubled by the misfortune of others who we hold dear. Why this should provide a reason to criminalise drug use in particular, is not easy to see. The same argument applies to social costs. Some people do not 'fit' into modern society's demands for success according to specific criteria related to income and wealth, social status, and similar. Rather, they fall on the outside of society and become - from the point of view of social economics - burdens to society, and emotional burdens to their families and friends. There can be a number of reasons for this to happen, but this does not provide a sufficient argument for criminalisation. On the contrary, taking alcohol as one example, this is instead used by the state as a source of income by means of high levels of taxation. Thus, it is not only a matter of inconsistency in this regard, there is also an element of hypocrisy. These arguments also have an additional challenge. Applying these arguments as a general argument for the criminalisation of for instance drug use implies the belief that every instance of drug use leads to, or represents a danger of, addiction or at least extensive drug abuse. This relates us once more back to the issue concerning the conception of the individual, its control over him- or herself, and also the empirical presuppositions concerning how addictive (different kinds of) drugs are. We will not here be able to dig into this, but it seems at least reasonable to claim that not all instances of drug use lead to addiction or extensive drug abuse. Given this, it seems that these arguments do not support anything more than criminalisation of extensive use of drugs.

The third argument is the signalling effect. The argument goes like this: The main concern with the decriminalisation of drug use is that it sends the signal to youngsters in particular that drug use is no longer considered as serious as it was previously. Consequently, one expects a significant increase in drug use among youngsters, which indeed is a concern. This argument merits particular consideration, as it seems particularly central to those who support the criminalisation of use and minor possession of drugs.

However, there are once again certain challenges to the argument that those who wish to make use of it should respond to. If we accept that (de)criminalisation has this kind of signalling effect, we must ask what the signal is and whether it represents such a significant concern that it warrants criminalisation of the signalling act. Here, we must take into 
account for instance the already extensive use of drugs among young people in Norway, and the potential counterproductive effects of criminalisation, i.e. in particular the forbidden fruit effect. ${ }^{65}$ Furthermore, a general principle is that criminalisation should not be more extensive than needed to secure the relevant goal. As the aim is clearly to protect youngsters, it should be considered if it would not be sufficient to prohibit the use and minor possession of drugs for (for instance) individuals under the age of 21 . Stated differently, is the criminalisation of all and every instance of drug use required in order to tell youngsters that they should abstain from drug use? In other settings, where the legislator is doubtful of young citizens' ability to make adequate practical decisions in matters that may have life-long consequences, solutions such as higher age limits have been applied. One example is the Sterilisation Act, which requires the individual to be 25 years of age before being allowed to make this kind of decision. ${ }^{66}$ It could even be questioned if not this would be a better signal for protecting youngsters from experimenting with drugs. One should, of course, expect a 'leakage' if adults are allowed to use drugs. ${ }^{67}$ However, in regard to pornography, for instance, adults are allowed to produce, purchase and consume non-offensive pornography (on offensive pornography, see s. 317 of the Penal Code), while distributing this kind of material to children is punishable (see for instance s. 298 as regards children below the age of 16 and also s. 317 first part c)).

As concerns the fourth argument, the crime generative effect, this seems more related to classical criminalisation arguments. This is a complex and empirically contingent argument, which we cannot dig into here. However, if this argument is to be applied as a justification for the contemporary criminal regulation of drugs, a lot of work is needed in order to clarify the argument itself and acquire a proper empirical basis for applying it. It is also worth reminding again of the fact that the state here seems to be involved in a negative loop. Fighting the war on drugs by means of criminal legislation seems to contribute to the high price level of drugs, leading to theft and similar crimes, and to the violent market that we described earlier. The engagement of criminal law seems in this way at least partly responsible for the crime generative effect and, one can say, more responsible the heavier this engagement is. Also, while this crime generative effect of drug use seems related in particular to economic crimes such as theft, the crime generative effect of alcohol seems more closely related to far more serious crimes, such as violence and sexual offences.

\footnotetext{
65 See on this Husak 2018.

66 See Lov om sterilisering av 3. juni 1977 nr. 57, s. 2.

67 On this kind of leakage, see Husak in Husak and de Marneffe 2005 p. 55 ff.
} 


\subsection{The Most Recent Development in Norway}

Hopefully, the foregoing remarks have shown that the current state of the law in this regard rests on too superficial a justification. None of the arguments considered above seem to give a clear-cut normative basis for the scope of the contemporary regulation. This is so even if one adopts an 'overall' perspective which draws together different arguments. There are, however, certain arguments in favour of the criminalisation of drug use that should be explored in more detail before any conclusions in this matter can be drawn.

Even if these considerations are only a first step towards an improved debate on the criminalisation issue, there is to some extent reason to believe that at least a somewhat more nuanced criminal regulation of drugs than the current one, should be considered. It is at least clear that more structure and quality in the debate can be achieved by more work on the criminalisation principles. The Criminal law commission's adoption of a harm principle was a step in the right direction, even if this did not manage to make the desired impact on the more specific criminalisation issues in the preparatory works, the drug issue included.

Reworking the principles for criminalisation of drug-related acts may, however, prove to be superfluous. In December of 2017, it was announced that a majority in the Health and Care Committee of the Parliament had added a note in the budget proposal for 2018 that use of drugs and possession for personal consumption should be moved from the justice sector to the health sector. This statement indicates that a person's own use of drugs and possession for such use will be handled as a public health issue in the future, which in that case marks a clear shift of opinions on this issue. This is, however, not binding on the government. Without legislative amendments, there are no guarantees that the statement will lead to a reform or other measures that will have the desired effects.

Even if the idea is followed up by the legislator, it is quite unclear what kind of regulation we are talking about here. ${ }^{68}$ However, it is possible to spot a few plausible alternatives. One of the most important observations is that several of the largest parties in Parliament have expressed that the statement by the Health and Care Committee is not to be interpreted as implying legalisation of the use of drugs and possession for personal consumption, but that it is a matter of decriminalisation..$^{69}$ This leaves some uncertainty as to what the legal consequences of such acts may be. The fact that this form of drug-related activity will still be illegal indicates that the acts can or may still be sanctioned. This may lead to the establishment of new administrative sanctions, such as administrative fines (which, as mentioned, the Sanctioning commission rejected). Another option is some

68 See also Marthinussen in this volume.

69 The Conservative Party, the Labour Party, the Socialist Party, the Communist Party and the Liberal Party are in favor of decriminalisation, but it seems, not for legalisation. The Progress Party and the Christian Democratic Party are opposed to decriminalisation. 
form of obligatory rehabilitation program, or different combinations of such measures. The scope of such alternative forms of reactions also remains unclear. It is, for instance, not clear whether such rehabilitation sanctions are intended for all drug users or only some of these (in the way the syringe rooms are available only for adults who are heavy heroin-abusers). There is even the alternative of including such rehabilitation sanctions in the criminal law. Rehabilitation sanctions are not uncommon to Norwegian criminal law. ${ }^{70}$ So, the criminal law may very well remain a central piece of the Norwegian legal regulation of drugs, even when it comes to personal use and minor possession. In other words, there is - at least not yet - reason to call off the debate on the role of criminal law in regulating use and possession of drugs. And, even if the reworked harm principle should prove to be superfluous in the drug (use) setting, there remain a number of other criminalisation issues in Norwegian criminal law that would benefit from this work.

\section{The Level of Punishment}

\subsection{The Development and the Debates}

The focus so far has been on the question of criminalisation, and if the extensive criminalisation of drug-related activity can be justified based on the harm principle. However, the most problematic point in the Norwegian criminal regulation of drugs is the high levels of punishment. As mentioned initially in this article, freedom as a fundamental value entails that it is criminalisation, and not legalisation, that has to be justified by the legislator. While the criminalisation of an act means that the act is considered harmful, the level of punishment applied represents a continuation of this viewpoint in the sense that the punishment must reflect the degree of harm caused by an act. This means that the harm principle does not, and should not, lose its significance when deciding on the severity of the sanctions. But before we look closer at the current regulations and to what extent the levels of punishment mirror the harmful effects of drug-related crimes, it is necessary to clarify how the sanctioning of drug crimes has evolved over time. This is because the current regulations are a result of a dramatic, clearly politically founded - it is tempting to say uncontrolled - increase of punishment for drug offences by a series of legislative amendments between 1968 and 1984.

Prior to 1968, the maximum penalty for involvement with drugs was set to two years of imprisonment in s. 43 of the former Medicine Act. ${ }^{71}$ The decision was then made to

70 See further the outline of the criminal sanctions in Gröning, Husabø and Jacobsen 2016 pp. 607 ff.

$71 \quad$ Prior to 1964, the maximum penalty was 6 months of imprisonment, see Ot.prp. nr. 28 (19631964) Om lov om legemidler og gifter m.v. p. 20 and Innst. O. XVII (1963-64) Innstilling fra sosialkomitéen om lov om legemidler og gifter m.v. p. 8. 
regulate the more serious forms of drug offences in s. 162 of the Penal Code of 1902, where the maximum penalty was set to six years. A few years later, in 1972, it was further increased to 10 years. But despite the fact that the maximum sentence rose from six to 10 years in a span of four years, the development did not stall for more than nine years. In 1981 the maximum penalty was once again increased to 15 years, before it reached its highest point in 1984 when it was finally set to 21 years in cases involving highly aggravating circumstances. This provision was carried forward into the new Penal Code of 2005, and, as mentioned above, placed in the second sentence of s. 232.

When the penalty for drug crimes was increased to 10 years in 1972, the previous maximum penalty of six years had not yet been applied by a Norwegian court, and the highest punishment that had been applied was 5 years. ${ }^{72}$ Despite of this, the Ministry of Justice found the increase necessary to combat any further rise in professional drug crimes. The general preventive effects that a strict penalty could result in (or help uphold) were particularly emphasised.$^{73}$ In 1981 , the Ministry once again stated that stricter penalties could have such effects, but also held that there were no empirical studies that could provide a uniform answer to the question and that there was no 'clear connection' between strict penalties and a low rate of drug trafficking. ${ }^{74}$ There was also a somewhat stronger focus on the idea that the penalty should reflect the seriousness of the offence. ${ }^{75}$ 15 years of imprisonment was therefore considered an adequate punishment, despite the uncertainties attached to its general preventive effects.

In 1984 , when the penalty finally rose to 21 years, which is also the general maximum penalty in Norwegian criminal law, the Criminal law council (Straffelovrådet) did express scepticism about the amendment. It was held that although the strict punishments had been aimed at combatting professional drug criminals, studies indicated that most of the persons convicted were also users of drugs, often from difficult social backgrounds. Another important observation was that the level of punishment applied in Norwegian law already surpassed that of the other Nordic countries in regard to drug crimes. And because the maximum penalty was set as high as 15 years, the Criminal law council stated - just as the Ministry of Justice had in 1981 - that a further increase in the penalty could not be expected to lead to a corresponding increase in its crime-preventive effects. The council therefore explicitly stated that it did not consider it necessary to make any amendments to the levels of punishment applied by the courts. ${ }^{76}$ Despite of this, a proposal was made to increase the maximum penalty to 21 years, but only in cases con-

72 See Ot.prp. nr. 5 (1971-1972) Om lov om endringer i den alminnelige borgerlige straffelov 22. mai 1902 nr. 10 p. 4.

Ibid., pp. 4-5.

See Ot.prp. nr. 62 (1980-1981) Om lov om endring i straffeloven $m$ m p. 28.

Ibid., pp. 26-28.

See NOU 1982: 25 Narkotikalovbrudd, ran og heleri p. 33. 
cerning involvement with large quantities of the more dangerous forms of drugs. ${ }^{77}$ The Ministry of Justice feared that this reservation would send the wrong signal of a wider social acceptance of other drugs, and the maximum sentence of 21 years was therefore made applicable for all drug types. ${ }^{78}$

The question once again arose in the preparatory works of the Penal Code of 2005. As was described in chapter 2 of this article, the Criminal law commission was split on the issue of decriminalisation of certain forms of drug-related activity. There was, however, no disagreement on the question of the levels of punishment. The Commission argued that the level of punishment should be reduced, and wished to follow up the Criminal law commission's proposal to distinguish between the particularly dangerous and less dangerous types of drugs. ${ }^{79}$ But the proposal went even further, as the Commision recommended that the penalty for drug crimes be reduced to a maximum of six years except in cases concerning gross violations, where the maximum penalty would be set to 10 years. A maximum penalty of two years was suggested for negligent gross violations. ${ }^{80}$ Once again, the Ministry of Justice criticised the proposed amendment. ${ }^{81}$ It was considered necessary to have a maximum penalty of 21 years to combat professional drug traffickers, and the other reductions were deemed too drastic as well.

\subsection{The Principles of Sentencing}

The development that has taken place since 1968 not only shows that there has been a dramatic increase in the punishments applied to drug crimes, but also that there has been significant doubt as to whether the strict punishments have been appropriately justified. This reveals differing views on the principles of sentencing, and sometimes also an absence of such principles in the discussions regarding such crimes. It is therefore necessary to ascertain which considerations have been considered relevant when determining the levels of punishment for drug crimes, and if the levels of punishment for such crimes can be convincingly justified on the basis of these considerations.

In criminal law, the idea of the general preventive effects of punishment is often used as an argument for criminalising unwanted acts. And as follows from the debates in the

77 Ibid., p. 34-35. More specifically, the Criminal law council argued that the maximum penalty of 21 years should be applicable in cases involving a very substantial quantity of heroin, morphine, amphetamine, cocaine, LSD and other similarly dangerous drugs. This would primarily exclude hashish and marijuana.

78 See Ot.prp. nr. 23 (1983-1984) Om lov om endringer $i$ straffeloven m.v. p. 19.

79 See NOU 2002: 4 pp. 331-332.

$80 \quad$ Ibid., p. 337.

81 See Ot.prp. nr. 22 (2008-2009) pp. 97-100. 
preparatory works, the theory of general deterrence is also referred to as an argument for harsh punishments. Its relevance is especially evident when discussing the regulation of drug crimes, because the main goal has been to combat professional drug trafficking. This is a form of crime where one has reason to believe that the risks are often calculated in advance, unlike for example impulsive crimes or crimes of passion. But as it has also been pointed out several times, the general preventive effects are not only (highly) uncertain, but also not very likely to deter a person from committing a crime when the punishment is already set as high as it has been since the 70s and 80s. For a person who is willing to risk receiving a punishment of 15 years, an addition of six years will most likely not discourage him or her from committing the crime. In addition to this uncertainty attached to the effects of the increased punishments, the strong focus on the general preventive effects in the preparatory works is also difficult to reconcile with the principle of proportionality, which we will soon return to. This guideline is therefore problematic in several ways.

As for the other side of the theory of the deterrence, which is the idea that punishment may prevent future offences from the person who committed the crime, it must be borne in mind that harsher punishments may not have the desired effects. Persons convicted of drug crimes do not represent a homogenous group. Even though the harshest punishments are aimed at professional drug traffickers, it is also a fact that many of the persons who are convicted of drug crimes are users of drugs themselves. ${ }^{82}$ The drug abuse is often rooted in a more complex personal history, and longer prison sentences can make the road to recovery and back to society more difficult. This is also a likely reason why specific deterrence has not been particularly emphasised as a motivating factor behind the increased punishments.

As indicated above, a more general guideline for sentencing can be found in the principle of proportionality, which is the idea that the punishment must reflect the seriousness of the crime. ${ }^{83}$ Expressed in different terms, it must mirror the degree of harm caused to values that are protected by the legal order. In this context, the principle of proportionality can therefore be seen as a manifestation of the harm principle and its relation to the principle of guilt. The principle of proportionality explains, for example, why the maximum sentence for violations and gross violations is not the same. This is also why the courts attach weight to factors such as the amount and purity of the drugs sold, and whether the crime consists of production, import or sales of drugs or possession and purof proportionality in Norwegian criminal law, and states that the principle is 'deeply rooted' in our culture. The high levels of punishment for drug crimes are mentioned as an example of punishments that may not be proportional. 
chase for own use, when determining the concrete punishment. ${ }^{84}$ However, the steep rise in the maximum sentences for drug-related crimes does raise the question if it is possible to reconcile the levels of punishment with the principle of proportionality. An affirmative answer to this question presupposes that the punishment can be adequately justified by both sides of the principle of proportionality: The punishment must be absolutely and relatively proportional. ${ }^{85}$

The requirement of absolute proportionality entails that the punishment cannot be set higher than what is necessary to mark the harmful effects of an act. On a general level, this is a difficult assessment to make because determining which values are protected by the legal order, what harm is, and how it is measured requires the use of value-based discretion. On the other hand, the discussions in section 4 of this article show that these questions could and should have been answered more thoroughly by the legislator in regard to drug crimes. Without a more principled approach to the question of criminalisation, it is also difficult to justify the harsh sanctions in a convincing manner. While it is true that the Norwegian sanctioning of drug crimes is not the strictest in a European (and even global) context, and for that reason may not be considered irreconcilable with the principle of absolute proportionality, it does differ significantly from the regulations found in the other Nordic countries that have similar legal traditions. ${ }^{86}$

The maximum penalty for drug crimes is 10 years of imprisonment in Sweden and Finland. In Denmark, the maximum is 16 years in certain cases involving particularly dangerous drugs, but otherwise it is 10 years. ${ }^{87}$ The Ministry of Justice did express that it was desirable to have similar levels of punishment in the Nordic countries, but did not consider this a decisive factor against the Norwegian regulations. ${ }^{88}$ No further attempts were made to justify the disparity. Viewed from the perspective of proportionality, it is

84 See for example Rt. 2003 p. 1082 and Rt. 2008 p. 1373, which both concern low-purity drugs. In the latter, the Supreme Court specifically states that the punishment for drug crimes 'to a large extent' is determined by the potentially harmful effects caused by the spread of drugs. See also Matningsdal 2016 pp. $34 \mathrm{ff}$. for a general review of the case law concerning drug offences.

85 According to the mandate of the Criminal law commission, the relative side of the principle of proportionality (referred to as 'the idea of equivalence' in the preparatory works and below) was to be a 'central' guideline when determining the levels of punishment in the new criminal code, see NOU 2002: 4 pp. 124-125.

86 See Träskman 2005 p. 242 : 'But when it comes to the severity of sanctions for drug offences there is no incongruity between the laws in the Nordic countries and the requirements expressed in the EU framework decision laying down minimum provisions on the constituent elements of criminal acts and penalties in the field of illicit drug trafficking... In general, the actual punishments imposed for offences in the Nordic countries are rather close to the minimum punishment indicated in the penalty scale ... There is strictly speaking only one exception, drug offences.'

87 See Christie and Bruun 2003 pp. 106-112 for a closer comparison of the regulations in the Nordic countries. See Ot.prp.nr. 22 (2008-2009) p. 98. 
therefore not only difficult to justify the fact that the Norwegian sanctioning differs from what appears to be the standard in other comparable countries, but also that it has been considered necessary to set the maximum sentences twice as high as in these countries so as to mark the harmful effects of the crimes in question.

The harsh punishments are even more questionable when held up against the idea of equivalence, which is another aspect of the principle of proportionality. This side of the principle requires that the punishment for an offence is also relatively proportional, meaning that crimes which produce similarly harmful effects must be sanctioned in a similar manner. The argument does therefore not focus so much on the punishment in itself, but on the system of which the punishment forms a part. It is difficult to argue that this aspect of the principle is respected when drug offences are subject to similar punishments as murder. Imprisonment for 21 years is the general maximum of Norwegian criminal law (apart from international crimes such as genocide and the most serious acts of terrorism, for which one may receive 30 years of imprisonment). The above-mentioned case from 2017 involving a police officer who was sentenced to 21 years of imprisonment for his participation in the import of very significant amounts of hashish, serves as an example that drug crimes can lead to the application of the maximum penalty not only in theory but also in practice.$^{89} \mathrm{It}$ is hard to see how this can be reconciled with the fact that murder also has a maximum of 21 years imprisonment.

While most will certainly consider both murder and professional drug trafficking to be serious crimes, murder represents a more direct form of physical harm where there is (most usually) no element of choice on the part of the victim. It is therefore not surprising that the distinction between the direct and indirect forms of harm has been a point of discussion in the preparatory works in regard to the level of punishment, but still has not led to a decrease in the maximum penalties for drug crimes. ${ }^{90}$ This must be seen in light of the strong focus on professional drug crimes in the preparatory works. On this point, the theory of general deterrence appears to have weighed heavier than more system-based arguments such as the principle of equivalence.

Although the maximum penalties found in the criminal legislation are harsh, the courts may, as mentioned earlier, consider a range of factors when determining the punishment in a specific case. As we have seen in chapter 4, use of drugs and possession for such use is still criminalised in Norway. However, if the offence is related to the person's own drug abuse, this a consideration that will normally lead to a milder punishment. ${ }^{91}$ The Supreme Court's judgment in Rt. 2009 p. 1551, which concerned the import of 3,9

89 For a summary of the case in English, see for example https://www.reuters.com/article/us-norwaypolice-verdict/norwegian-policeman-jailed-for-21-years-in-drugs-case-idUSKCN1BT1QZ (last accessed 21.03.18).

$90 \quad$ See especially NOU 2002: 4 p. 337 and Ot.prp. nr. 22 (2008-2009) pp. 93 and 98-99.

$91 \quad$ See especially Rt. 1999 p. 33, and Rt. 2009 p. 1551. 
grams of cannabis for own use, gives an example of this. The Court emphasised that the drugs were purely meant for personal consumption, and the person was therefore only convicted to a fine of 6000 NOK (approximately 620 Euros). And while crimes involving large quantities of less serious forms of drugs can still lead to the application of the maximum penalty (as illustrated above), the level of punishment applied for involvement with cannabis has generally been lowered. ${ }^{92}$ The criticism towards the Norwegian regulations has especially focused on these two factors, and while it has thus far not led to the decriminalisation of use of drugs or less harmful drug types, or changes in the maximum penalties for such offences, the lower degree of harm caused by such acts does reflect itself in the courts' sentencing practice. This does not, however, alter the principally problematic aspects of the levels of punishment laid down in the criminal legislation. 